\title{
Genetic Variability and Character Association of Yield Components in Maize (Zea mays L.)
}

\author{
Sumayea Khan, Firoz Mahmud \\ Department of Genetics and Plant Breeding, Faculty of Agriculture, Sher-e-Bangla Agricultural University, Dhaka-1207, \\ Bangladesh \\ Email: sumayeakhansau@gmail.com
}

How to cite this paper: Khan, S. and Mahmud, F. (2021) Genetic Variability and Character Association of Yield Components in Maize (Zea mays L.). American Journal of Plant Sciences, 12, 1691-1704. https://doi.org/10.4236/ajps.2021.1211118

Received: October 6, 2021

Accepted: November 22, 2021

Published: November 25, 2021

Copyright $\odot 2021$ by author(s) and Scientific Research Publishing Inc. This work is licensed under the Creative Commons Attribution International License (CC BY 4.0).

http://creativecommons.org/licenses/by/4.0/

\section{Open Access}

\begin{abstract}
The research investigation was carried out in the experimental area of Sher-eBangla Agricultural University, Sher-e-Bangla Nagar, Dhaka-1207, during the late Rabi season Mid December to May 2018 to study the genetic variability and character association of yield components in Maize with 35 maize genotypes as experimental materials that were laid out in Randomized Complete Block Design (RCBD) with three replications. The research work was oriented to calculate and estimate the yield factor through analyzing the mean performances, variability, heritability, genetic advance, correlation coefficient and path analysis involving the yield contributing characters. The maximum yield per plant $(117.51 \mathrm{~g})$ was estimated in the genotype G12 (Pacific) and the minimum yield per plant $(51.89 \mathrm{~g}$ ) was recorded in the genotype G17 (Dekalb Super). The phenotypic coefficient of variation was observed higher than the genotypic coefficient of variation for all yield contributing characters. Heritability was also shown higher compared to genetic advance in comparative mean study for all the characters involved. Significant and positive correlation was observed for grain yield per plant with plant height (0.774), cob length (0.956), grain per row (0.703) and 100-seed weight (0.365). In path analysis study, positive direct correlation was recorded in days to male flowering (0.247), cob breadth (1.078), number of grains per cob (6.874) and 100 -seed weight (0.595).
\end{abstract}

\section{Keywords}

Component, Formatting, Style, Styling

\section{Introduction}

Maize (Zea mays L.) is the 3rd most significant cereal crop after wheat and rice 
in the world [1]. It is also commonly known as Corn (mostly in North America) originating in the Andean region of Central America and basically first domesticated by indigenous people in southern Mexico. After domestication, maize spread quickly through North and South America, reaching the northeastern US and southern Canada prior to European colonization. Maize spread rapidly throughout Europe and from Europe to other parts of the world after the European discovery of the Americas [2]. Maize (Zea mays L.) is an important staple crop of the world after wheat and rice. At the same time, it is a versatile crop due to its multifarious uses as feeds, food and industrial raw material. The crop serves as a source of basic raw material for a number of industries viz., starch, protein, oil, alcoholic beverages, food, sweeteners, cosmetics and biofuels [3].

In Bangladesh in the year 2013-14, 2014-15 and 2015-16, the production of maize was 2,123,572 MT, 2,271,998 MT and 2,445,578 MT, respectively [3]. The area under maize cultivation has quickly increased to 804 thousand acres of land in FY 2014-15 from 72 thousand acres in FY 2003-04 [4] [5]. So, the production of maize in Bangladesh is continuously increasing. Among the different districts in Bangladesh-Dinajpur, Chuadanga, Takurgaon, Lalmonirhat, Rajshahi, Kushtia, Rangpur and Bogra are noted to be more progressive in maize production with higher rates of growth. Both composite and hybrid maize are grown well in the loam and sandy-loam soils of the country (with three to four irrigations). Hybrid maize has a greater yield with 2.4 tons/acre (5.4 tons per ha), which is higher by one-third than composite maize ( 1.47 tons/acre or 3.63 tons/hectare) [6].

Yield is a complex inherited character resulting from the interaction between the vital processes [7] and associated with various contributing characters, therefore, direct selection for yield per se may not be the most efficient method for its improvement, but indirect selection for other yield related characters, which are closely associated with yield and high heritability estimates will be more effective [8]. In the year 2017/2018, the United States was the largest producer of corn with a production volume amounting to about 370.96 million metric tons. China and Brazil rounded off the top corn producing countries. Total maize production in Maize output increased the most, reaching a record in 2017, driven largely by higher production in several major exporting countries. Wheat output was high but slightly below the record set in 2016, and other coarse grain output declined in 2017 due mainly to lower barley production in Australia and lower sorghum and barley production in the United States. Global maize production is expected to grow by $161 \mathrm{Mt}$ to 1.2 billion tons over the next decade, with the largest increases in China (31 Mt), followed by Brazil $(24 \mathrm{Mt})$, the United States (22 Mt), the European Union (11 Mt) and Argentina (10 Mt). Increased production in Brazil will be largely driven by higher second-crop maize following soybeans. Production growth in the United States is expected to slow to less than $1 \%$ p.a. over the next ten years, compared to $2.4 \%$ p.a. the decade before, due to slower growth in domestic demand, particularly for ethanol, and increased export competition [9]. 
A successful selection program depends not only on heritability of desirable characters but also on the information about the association among various yield component characters and their association with grain yield [10] [11]. Variability is the differences between individuals in a population due to genetic composition and growing environment [12]. The existence of variability is utmost role as success of any plant breeding program depends on the genetic variability and selection skill of plant breeder [13]. Selection is only effective if the parent population has significant amount of variability. Phenotypic coefficient of variation (PCV) and genotypic coefficient of variation (GCV) provides insight information on magnitude of variability in a population and heritability shows the component of a character transmitted to future generations [14] [15]. Furthermore, heritability coupled with genetic advance shows the expected genetic gain in next generation [16]. In addition, correlation between yield and yield attributing traits are prime important for indirect selection for those traits which have high heritability and closely associated to contribute to improving yield [17]. This study was conducted to elaborately understand about the genetic parameters and character associated attributes to consider the yield and its components involving 35 Maize populations to achieve following objectives: To know the yield potentiality of different maize genotypes, to understand the nature of association of traits, direct and indirect relation between yield contributing characters of maize genotypes and to study genetic variability among the genotypes.

\section{Materials and Methods}

The research work was conducted in the experimental field of Sher-e-Bangla Agricultural University, Sher-e-Bangla Nagar, Dhaka-1207, during Rabi season (Mid December to May 2018). Sher-e-Bangla Nagar Thana (Dhaka metropoli$\tan )$ area $5.25 \mathrm{sq} \cdot \mathrm{km}$, located in between $23^{\circ} 45^{\prime}$ and $23^{\circ} 47^{\prime}$ north latitudes and in between $90^{\circ} 22^{\prime}$ and $90^{\circ} 23^{\prime}$ east longitudes. The soils of this AEZ have been developed from the Madhupur Clay and occupy a large area of $4244 \mathrm{~km}^{2}$ [18]. Madhupur Tract or Red Soil Tract is a forest-based land. The area is also known for the production of mango, banana, pomelo and pineapple. But deforestation in the last few decades has made a great loss to the environment which will not be recovered in future [19]. The optimum soil pH is 6.6 - 7.3 [20]. 35 Maize genotypes were used to execute the experiment in $360 \mathrm{msq}$ of land in three replications during 2017-2018 (Rabi season) cropping season. The germination percentage of the genotypes was satisfactory, uniformed with $94 \%$ - $96 \%$ respectively. The experiment was designed and laid out in Randomized Complete Block Design (RCBD) with 3 replications. The supplied experimental land was 360 msq in total. The field was divided into 3 blocks and the individual block size was $3 \mathrm{~m} \times 30 \mathrm{~m}$. Spacing was maintained $60 \mathrm{~cm} \times 20 \mathrm{~cm}$, row to row distance was $60 \mathrm{~cm}$, line to line distance was $20 \mathrm{~cm}$, block to block distance was $1 \mathrm{~m}$. The Genotypes were distributed randomly without biasness (Table 1). Green manure 
and decomposed organic matter were used at the rate of 6 ton/ha before final land preparation. For land preparation chemical fertilizers were applied such as Urea (14 kg), TSP (8 kg), MOP (6 kg), Gypsum (6 kg), Zinc Sulphate (1 kg) and Boric Acid $(1 \mathrm{~kg})$ in $360 \mathrm{~m}^{2}$ of the experimental land. The rest amount of Urea was applied 25 days after the first installment. The 35 maize genotypes were planted in lines each having a line-to-line distance $20 \mathrm{~cm}$ and row to row distance $60 \mathrm{~cm}$ under direct planting in well prepared plot on 20 December 2017. The data obtained for different characters were statistically analyzed to find out the significance of the difference among the maize genotypes. The mean values of all the characters were evaluated and analysis of variance was performed by the "F" test. The significance of the difference among the treatment means was estimated by the Duncan's Multiple Range Test (DMRT) test at 5\% level of significance [21]. By applying following formulae for genotypic \& phenotypic variance, genotypic and phenotypic coefficient of variation, estimation of genetic advance, heritability and multivariate analysis were estimated with GENSTATE 4.2 program.

\section{Results and Discussion}

\subsection{Analysis of Variance}

Analysis of variance was carried out to partition the variances into its components. The results of the analysis revealed highly significant differences among the mean values for all traits i.e., days to male flowering, days to female flowering, days to maturity, plant height, cob length, cob breadth, number of rows per cob, number of seeds per row, 100-seed weight and yield per plant.

\subsection{Genetic Variability, Heritability and Genetic Advance}

Prominent variation and significant differences in genetic variability, heritability and genetic advance are depicted in Figure 1 and Figure 2. Also a cooperative study has been carried out and presented in Table 2 .

Phenotypic coefficient of variance (3.34) was higher than genotypic coefficient of variance (2.69) and environmental coefficient of variance (1.98) (Table 2). Heritability was recorded 64.82 and genetic advance was 2.9 at $5 \%$ level of significance. Days to male flowering was positively and significantly correlated with the other traits (days to female flowering, days to maturity, plant height, cob breadth, row per cob, seed per row, seed per cob, 100 seed weight and yield per plant).

The phenotypic, genotypic as well as environmental variances for this character were estimated 5.41, 3.53 and 1.87 (Table 2). Phenotypic coefficient of variance (3.79) was higher than genotypic coefficient of variance (3.06) and environmental coefficient of variance (2.23) (Table 2). Heritability was recorded 65.33 and genetic advance was estimated at 3.13 at $5 \%$ level of significance. Days to female flowering was positively and significantly correlated with the other traits (days to male flowering, days to maturity, plant height, cob length, cob breadth, row per cob, seed per row, seed per cob, 100 seed weight and yield per plant). 
Table 1. Name and source of the genotypes used in the experimental study.

\begin{tabular}{|c|c|c|c|}
\hline Serial Number & Genotypic code & Genotypes & Source of collection \\
\hline 1. & G1 & ВНМ-13 & BARI \\
\hline 2. & G2 & BHM-12 & BARI \\
\hline 3. & G3 & BHM-14 & BARI \\
\hline 4. & G4 & BHM-5 (F1) & BARI \\
\hline 5. & G5 & BHM-5 (F3) & BARI \\
\hline 6. & G6 & BHM-6 (F1) & BARI \\
\hline 7. & G7 & BHM-6 (F3) & BARI \\
\hline 8. & G8 & BHM-7 & BARI \\
\hline 9. & G9 & PAC-399 & Lal Teer \\
\hline 10. & G10 & PAC-984 & Lal Teer \\
\hline 11. & G11 & PAC-60 & Lal Teer \\
\hline 12. & G12 & Pacific & Petrocem Co. \\
\hline 13. & G13 & Pacific-98 & Petrocem Co. \\
\hline 14. & G14 & HP-222 & Petrocem Co. \\
\hline 15. & G15 & Dekalb-30B07 & Agrovet limited \\
\hline 16. & G16 & Dekalb Super Gold & Agrovet limited \\
\hline 17. & G17 & Dekalb Super & Agrovet limited \\
\hline 18. & G18 & KhaiBhutta & BARI \\
\hline 19. & G19 & Krishibid-102 & Krishibid group \\
\hline 20. & G20 & Shuvra & BARI \\
\hline 21. & G21 & AS-999 (F1) & ACI \\
\hline 22. & G22 & AS-999 (F3) & ACI \\
\hline 23. & G23 & Uttaran & Lal Teer \\
\hline 24. & G24 & Misty & BARI \\
\hline 25. & G25 & NK-40 & Lal Teer \\
\hline 26. & G26 & Bio Seed & BARI \\
\hline 27. & G27 & Pioneer & Petrocem Co. \\
\hline 28. & G28 & PAC-559 & Lal Teer \\
\hline 29. & G29 & Duranta & Ispahani \\
\hline 30. & G30 & Cornell & Ispahani \\
\hline 31. & G31 & Kaveri (218) & Ispahani \\
\hline 32. & G32 & Kohinor-1820 & Lal Teer \\
\hline 33. & G33 & Kohinor & LalTeer \\
\hline 34. & G34 & Chamak-07 & Supreme Seed Co. \\
\hline 35. & G35 & Golden-984 & Supreme Seed Co. \\
\hline
\end{tabular}


$\square \mathrm{GCV}=\mathrm{PCV}$

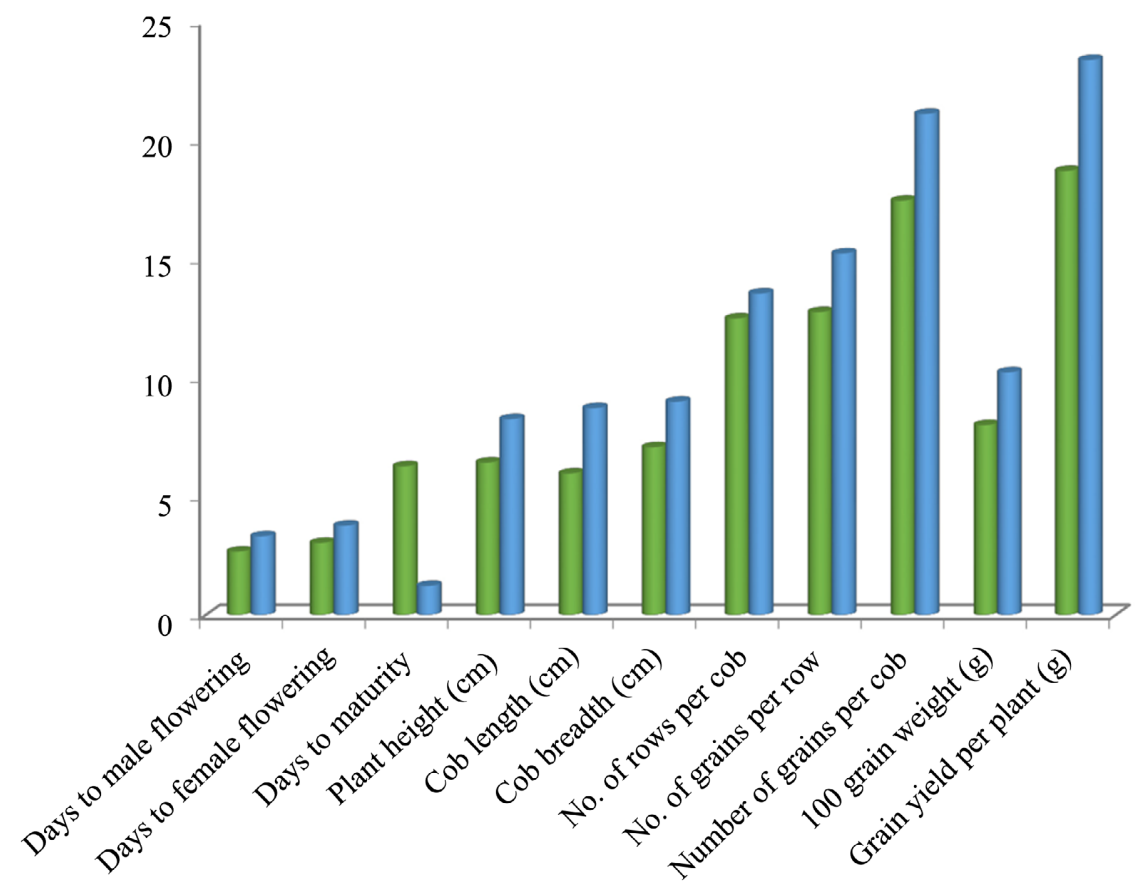

Figure 1. Genotypic and phenotypic variability in maize.

neritability $\quad$ Genetic advance $(\%$ mean $)$

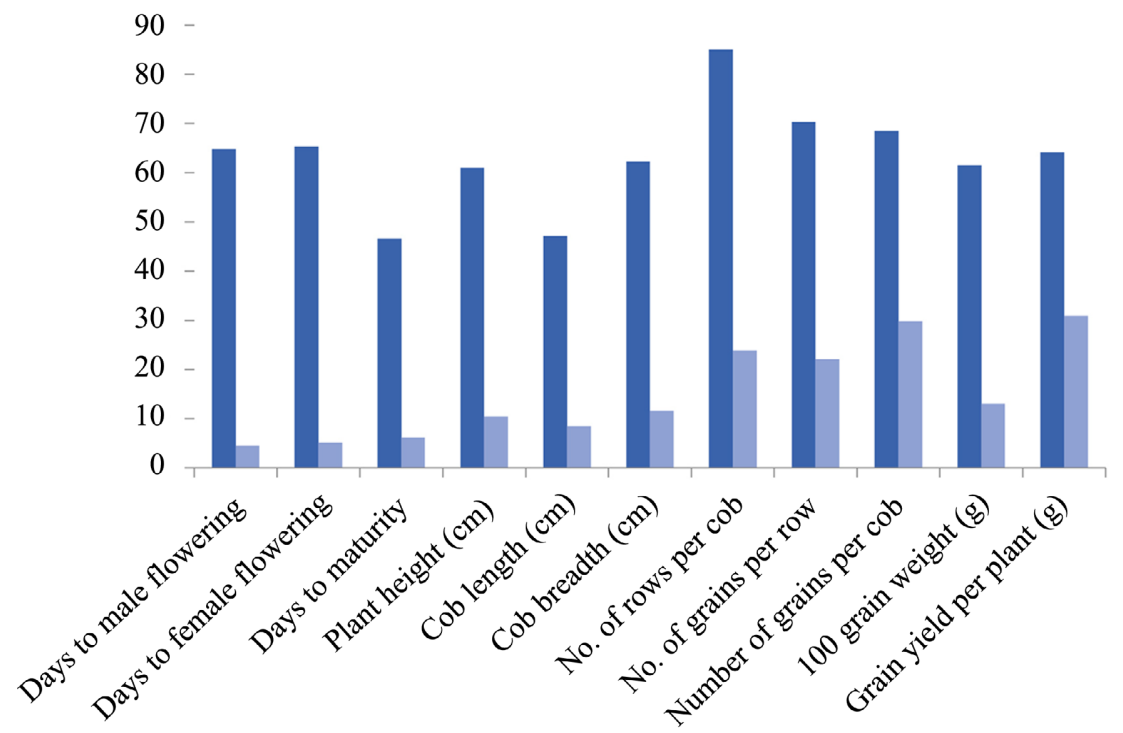

Figure 2. Heritability and genetic advance as percent over mean in maize.

The phenotypic, genotypic as well as environmental variances for this character were estimated 2.52, 0.16 and 2.36 (Table 2). Phenotypic coefficient of variance (1.23) was not higher than genotypic coefficient of variance (6.32) and environmental coefficient of variance (7.19) (Table 2). Heritability was recorded 46.53 and genetic advance was estimated at 2.21 at $5 \%$ level of significance. Days 
Table 2. Estimation of genetic parameters for different characters in Mazie.

\begin{tabular}{|c|c|c|c|c|c|c|c|c|c|}
\hline Parameters & $\sigma^{2} \mathrm{p}$ & $\sigma^{2} g$ & $\sigma^{2} \mathrm{e}$ & PCV & GCV & ECV & h2 & $\begin{array}{c}\text { GA } \\
(5 \%)\end{array}$ & $\begin{array}{c}\text { GA } \\
s(\% \text { mean })\end{array}$ \\
\hline Days to male flowering & 4.71 & 3.05 & 1.66 & 3.34 & 2.69 & 1.98 & 64.82 & 2.90 & 4.46 \\
\hline Days to female flowering & 5.41 & 3.53 & 1.87 & 3.79 & 3.06 & 2.23 & 65.33 & 3.13 & 5.10 \\
\hline Days to maturity & 2.52 & 0.16 & 2.36 & 1.23 & 6.32 & 7.19 & 46.53 & 2.21 & 6.17 \\
\hline Plant height $(\mathrm{cm})$ & 393.00 & 239.66 & 153.34 & 8.30 & 6.48 & 5.19 & 60.98 & 24.90 & 10.43 \\
\hline Cob length (cm) & 2.20 & 1.04 & 1.16 & 8.76 & 6.02 & 6.36 & 47.18 & 1.44 & 8.51 \\
\hline Cob breadth $(\mathrm{cm})$ & 1.91 & 1.19 & 0.72 & 9.03 & 7.12 & 5.55 & 62.26 & 1.77 & 11.58 \\
\hline No. of rows per cob & 3.67 & 3.12 & 0.55 & 13.58 & 12.53 & 5.25 & 85.08 & 3.36 & 23.80 \\
\hline No. of seeds per row & 30.79 & 21.66 & 9.13 & 15.26 & 12.80 & 8.31 & 70.34 & 8.04 & 22.11 \\
\hline Number of seeds per cob & $11,774.55$ & 8061.16 & 3713.39 & 21.13 & 17.48 & 11.87 & 68.46 & 153.04 & 29.80 \\
\hline 100-seed weight (g) & 10.66 & 6.56 & 4.11 & 10.27 & 8.05 & 6.37 & 61.50 & 4.14 & 13.00 \\
\hline Yield per plant (g) & 365.79 & 234.50 & 131.28 & 23.39 & 18.73 & 14.01 & 64.11 & 25.26 & 30.89 \\
\hline
\end{tabular}

$\sigma^{2} \mathrm{p}$ : Phenotypic variance; $\sigma^{2} \mathrm{~g}$ : Genotypic variance; $\sigma^{2}$ : Environmental variance. PCV: Phenotypic coefficient of variation GCV: Genotypic coefficient of variation ECV: Environmental coefficient of variation. h2: Heritability; GA (5\%): Genetic advance (5\%); GA (\% mean): Genetic advance (\% mean).

to maturity was positively and significantly correlated with the other traits (days to male flowering, days to female flowering, days to maturity, plant height, cob breadth, row per cob, seed per row, seed per cob, 100 seed weight and yield per plant).

Height is one of the most heritable and easily measured traits in maize [22]. The phenotypic and genotypic variability observed and presented in Figure 1. The phenotypic variability (around 9) was recorded higher in terms of genotypic variability (around 7).

The phenotypic, genotypic as well as environmental variances for this character were estimated 2.20, 1.04 and 1.16 (Table 2). Phenotypic coefficient of variance (8.76) was higher than genotypic coefficient of variance (6.02) and environmental coefficient of variance (6.36) (Table 2). Heritability was estimated 47.18 and genetic advance was recorded 1.44 at $5 \%$ level of significance. Cob length was positively and significantly correlated with the other traits (days to male flowering, days to female flowering, days to maturity, plant height, cob breadth, row per cob, seed per row, seed per cob, 100 seed weight and yield per plant). [23] [24] estimated higher heritability and genetic advance. The greater heritability means lower environmental effects.

The phenotypic, genotypic as well as environmental variances for this character were estimated 1.91, 1.19 and 0.72 (Table 2). Phenotypic coefficient of variance (9.03) was higher than genotypic coefficient of variance (7.12) and environmental coefficient of variance (5.55) (Table 2). Heritability was estimated 62.26 and genetic advance was recorded 1.77 at $5 \%$ level of significance. Cob 
breadth was positively and significantly correlated with the other traits (days to male flowering, days to female flowering, days to maturity, plant height, cob breadth, row per cob, seeds per row, 100 seed weight and yield per plant). [25] observed similar high heritability and genetic advance to contribute in yield characters.

The phenotypic, genotypic as well as environmental variances for this (Number of rows per cob) character were estimated 3.67, 3.12 and 0.55 (Table 2). Phenotypic coefficient of variance (13.58) was higher than genotypic coefficient of variance (12.53) and environmental coefficient of variance (5.25) (Table 2). Heritability for this trait was impressively higher (85.08\%) with compared lower genetic advance ( 3.36 at $5 \%$ level of significance) that reflects a positive relation and suitable selection for this character (Table 2 and Figure 3). [24] showed similar findings for the genotypes studied a wide range of variation for all the characters.

The phenotypic, genotypic as well as environmental variances for this (number of seeds per row) character were estimated 30.79, 21.66 and 9.13 (Table 2). Phenotypic coefficient of variance (15.26) was higher than genotypic coefficient of variance (12.80) and environmental coefficient of variance (8.31) (Table 2). Heritability for this trait was impressively higher (70.34\%) with compared lower genetic advance ( 8.04 at $5 \%$ level of significance) that reflects a positive relation and suitable selection for this character (Table 2 and Figure 2). In the findings of [25] recorded higher genetic advance for plant height, ear length, grains per row and grain yield.

The phenotypic, genotypic as well as environmental variances for this (number of seeds per cob) character were estimated 11,774.55, 8061.16 and 3713.39 (Table 2). Phenotypic coefficient of variance (21.13) was higher than genotypic

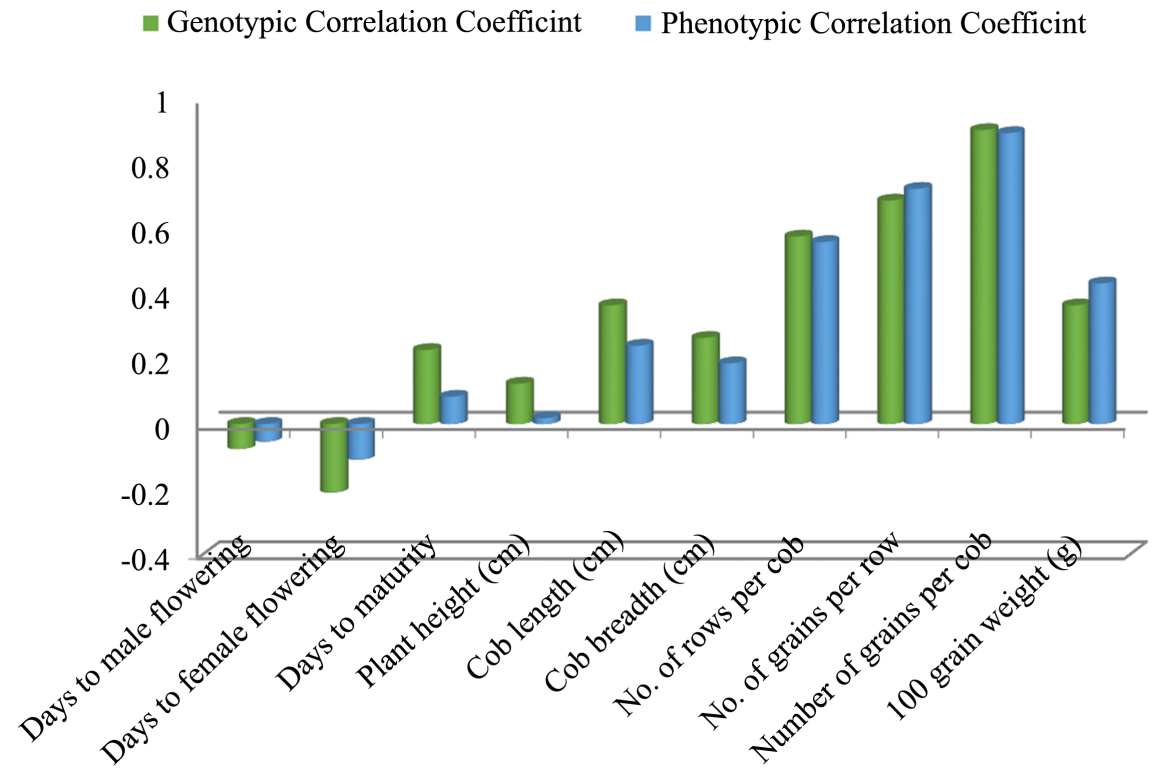

Figure 3. Graphical representation of genotypic and phenotypic correlation of yield contribution traits with yield. 
coefficient of variance (17.48) and environmental coefficient of variance (11.87) (Table 2). Heritability for this trait was impressively higher (\%) with compared lower genetic advance (153.04 at $5 \%$ level of significance) that reflects a positive relation and suitable selection for this character (Table 2 and Figure 2).

The phenotypic, genotypic as well as environmental variances for this (100-seed weight) character were estimated 10.66, 6.56 and 4.11 (Table 2). Phenotypic coefficient of variance (10.27) was higher than genotypic coefficient of variance (8.05) and environmental coefficient of variance (6.37) (Table 2). Heritability for this trait was impressively higher $(61.50 \%)$ with compared lower genetic advance (4.14 at $5 \%$ level of significance) that reflecting a positive relation and suitable selection for this character) (Table 2 and Figure 2). In the findings of [26] high to moderate estimates of GCV and PCV were recorded for Grain yield, number of kernels per row, 100-kernel weight, ear length and plant height which represent considerable variability and offer scope for genetic improvement through selection.

The phenotypic, genotypic as well as environmental variances for this (Total yield per plant) character were estimated 365.79, 234.50 and 131.28 (Table 2). Phenotypic coefficient of variance (23.39) was higher than genotypic coefficient of variance (18.73) and environmental coefficient of variance (14.01) (Table 2). Heritability for this trait was impressively higher (64.11) with compared lower genetic advance (25.26 at $5 \%$ level of significance) that reflects a positive relation and suitable selection for this character (Table 2 and Figure 2). [27] reported High values of genetic advance were obtained for grain yield.

\subsection{Correlation Analysis}

This investigation on yield and its component attributes as well as their inter relationship with direct and indirect contribution has profound importance in terms of future breeding programs. Yield is the ultimate result that is the combination of several components characters and environmental effects. Understanding the interaction of component characters among themselves with environmental factors plays crucial role in the implementation of plant breeding program. Analysis study on correlation factor provides information on the nature and extent of the characters association, between two pairs of metric characters. By considering this it would be possible to identify the genetic upgradation in one character by the selection of the other pair. Thus, this knowledge about character association will positively enhance the possible identification for higher yielding genotypes for future studies in breeding sector. The genotypic and phenotypic correlations between the pairs of character attributes are presented in Table 3 and Table 4. From the table, it can be depicted that the genotypic correlation coefficients among the different pairs of yield and its component contributing characters are mostly higher than the phenotypic correlation coefficient for different genotype of maize. The results are discussed below with the following attributes: Days to male flowering showed highly positive significant 
Table 3. Genotypic and phenotypic correlation coefficients among different pairs of yield and yield contributing characters for different genotype of Maize.

\begin{tabular}{|c|c|c|c|c|c|c|c|c|c|c|c|}
\hline & & $\mathrm{DMF}$ & DFF & $\mathrm{DM}$ & $\mathrm{PH}(\mathrm{cm})$ & $\mathrm{CL}(\mathrm{cm})$ & $\mathrm{CB}(\mathrm{cm})$ & RPC & GPR & GPC & $100 \mathrm{GW}(\mathrm{g})$ \\
\hline \multirow{2}{*}{ DFF } & $\mathrm{G}$ & $-0.431^{\star *}$ & & & & & & & & & \\
\hline & $\mathrm{P}$ & $-0.293^{\star *}$ & & & & & & & & & \\
\hline \multirow{2}{*}{$\mathrm{DM}$} & $\mathrm{G}$ & 0.120 & $-0.216^{*}$ & & & & & & & & \\
\hline & $\mathrm{P}$ & 0.013 & -0.084 & & & & & & & & \\
\hline \multirow{2}{*}{$\begin{array}{l}\mathrm{PH} \\
(\mathrm{cm})\end{array}$} & G & $0.226^{*}$ & $-0.664^{\star *}$ & -0.093 & & & & & & & \\
\hline & $\mathrm{P}$ & 0.145 & $-0.454^{\star *}$ & 0.175 & & & & & & & \\
\hline \multirow{2}{*}{$\begin{array}{c}\mathrm{CL} \\
(\mathrm{cm})\end{array}$} & G & 0.092 & $-0.542^{\star *}$ & 0.047 & $0.774^{\star *}$ & & & & & & \\
\hline & $\mathrm{P}$ & 0.042 & $-0.376^{\star *}$ & 0.076 & $0.634^{\star *}$ & & & & & & \\
\hline \multirow{2}{*}{$\begin{array}{l}\mathrm{CB} \\
(\mathrm{cm})\end{array}$} & G & -0.029 & $-0.448^{\star *}$ & $0.314^{\star \star}$ & $0.741^{\star \star}$ & $0.956^{\star *}$ & & & & & \\
\hline & $\mathrm{P}$ & -0.043 & $-0.370^{\star *}$ & 0.124 & $0.565^{\star *}$ & $0.877^{\star *}$ & & & & & \\
\hline \multirow{2}{*}{ RPC } & G & $-0.265^{\star \star}$ & 0.022 & $0.393^{\star \star}$ & -0.082 & 0.057 & 0.124 & & & & \\
\hline & $\mathrm{P}$ & $-0.223^{\star}$ & 0.010 & 0.107 & -0.125 & 0.043 & 0.093 & & & & \\
\hline \multirow{2}{*}{ GPR } & G & 0.094 & -0.004 & $0.245^{\star}$ & 0.012 & $0.206^{*}$ & 0.114 & -0.020 & & & \\
\hline & $\mathrm{P}$ & 0.059 & -0.003 & 0.097 & -0.014 & 0.153 & 0.070 & 0.049 & & & \\
\hline \multirow{2}{*}{ GPC } & G & -0.133 & 0.003 & $0.432^{\star *}$ & -0.034 & $0.205^{\star}$ & $0.195^{\star}$ & $0.698^{* *}$ & $0.703^{\star *}$ & & \\
\hline & $\mathrm{P}$ & -0.105 & 0.008 & 0.127 & -0.084 & 0.142 & 0.117 & $0.689^{* *}$ & $0.751^{\star *}$ & & \\
\hline \multirow{2}{*}{$\begin{array}{c}100 \mathrm{GW} \\
(\mathrm{g})\end{array}$} & G & 0.125 & $-0.519^{\star *}$ & $-0.303^{\star \star}$ & $0.323^{\star *}$ & $0.369^{\star \star}$ & 0.159 & -0.154 & 0.068 & -0.062 & \\
\hline & $\mathrm{P}$ & 0.097 & $-0.274^{\star *}$ & -0.035 & $0.210^{\star}$ & $0.249^{\star}$ & 0.163 & -0.125 & 0.103 & -0.002 & \\
\hline \multirow{2}{*}{$\begin{array}{l}\text { GYP } \\
(\mathrm{g})\end{array}$} & G & -0.077 & $-0.211^{\star}$ & $0.228^{*}$ & 0.124 & $0.365^{\star *}$ & $0.265^{\star \star}$ & $0.577^{\star *}$ & $0.688^{* *}$ & $0.905^{\star *}$ & $0.365^{\star *}$ \\
\hline & $\mathrm{P}$ & -0.054 & -0.110 & 0.084 & 0.018 & $0.241^{*}$ & 0.187 & $0.560^{* *}$ & $0.724^{\star *}$ & $0.896^{\star *}$ & $0.433^{\star *}$ \\
\hline
\end{tabular}

${ }^{* *}=$ Significant at $1 \% .{ }^{*}=$ Significant at $5 \%$.

Table 4. Partitioning correlation coefficient into direct (bold) and indirect effect.

\begin{tabular}{|c|c|c|c|c|c|c|c|c|c|c|c|}
\hline Characters & $\begin{array}{c}\text { Days to } \\
\text { male } \\
\text { flowering }\end{array}$ & $\begin{array}{l}\text { Days to } \\
\text { female } \\
\text { flowering }\end{array}$ & $\begin{array}{l}\text { Days to } \\
\text { maturity }\end{array}$ & $\begin{array}{l}\text { Plant } \\
\text { height } \\
(\mathrm{cm})\end{array}$ & $\begin{array}{c}\text { Cob } \\
\text { length } \\
(\mathrm{cm})\end{array}$ & $\begin{array}{c}\text { Cob } \\
\text { breadth } \\
(\mathrm{cm})\end{array}$ & $\begin{array}{c}\text { No. of } \\
\text { rows } \\
\text { per cob }\end{array}$ & $\begin{array}{c}\text { No. of } \\
\text { grains } \\
\text { per row }\end{array}$ & $\begin{array}{c}\text { Number } \\
\text { of grains } \\
\text { per cob }\end{array}$ & $\begin{array}{c}100 \text { grain } \\
\text { weight } \\
\text { (g) }\end{array}$ & $\begin{array}{c}\text { Genotypic } \\
\text { correlation } \\
\text { with yield }\end{array}$ \\
\hline $\begin{array}{c}\text { Days to } \\
\text { male } \\
\text { flowering }\end{array}$ & 0.247 & 0.013 & -0.033 & -0.035 & -0.103 & -0.031 & 1.092 & -0.385 & -0.917 & 0.074 & -0.077 \\
\hline $\begin{array}{c}\text { Days to } \\
\text { female } \\
\text { flowering }\end{array}$ & -0.107 & -0.031 & 0.059 & 0.103 & 0.607 & -0.483 & -0.090 & 0.016 & 0.023 & -0.309 & $-0.211^{\star}$ \\
\hline $\begin{array}{l}\text { Days to } \\
\text { maturity }\end{array}$ & 0.030 & 0.007 & -0.272 & 0.014 & -0.052 & 0.339 & -1.620 & -1.007 & 2.970 & -0.180 & $0.228^{*}$ \\
\hline $\begin{array}{c}\text { Plant } \\
\text { height } \\
(\mathrm{cm})\end{array}$ & 0.056 & 0.020 & 0.025 & -0.156 & -0.866 & 0.799 & 0.336 & -0.048 & -0.235 & 0.192 & 0.124 \\
\hline
\end{tabular}




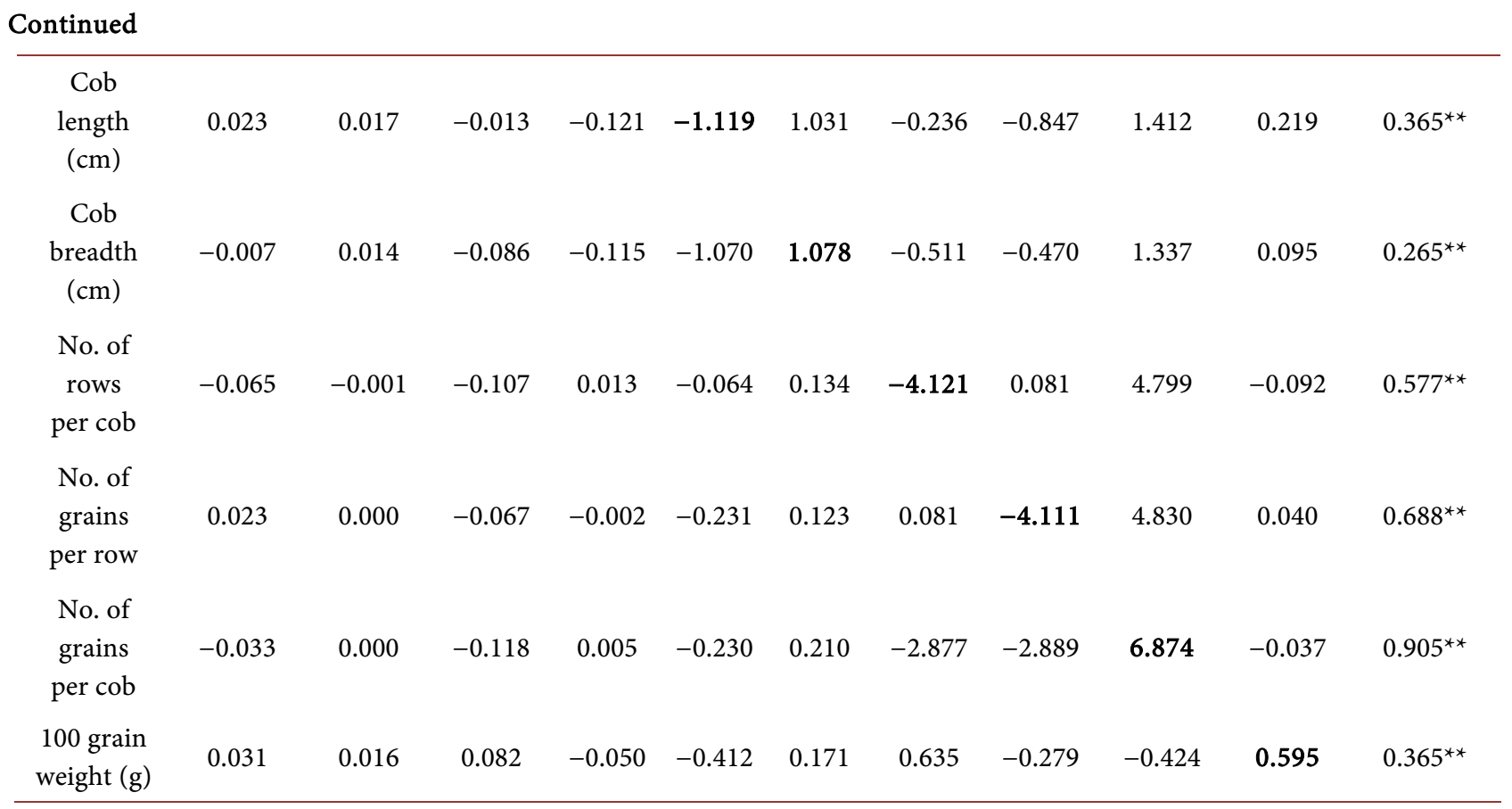

Residual effect: 0.016 .

correlation with plant height. Days to maturity showed highly positive and significant correlation with cob breadth, row per cob, seed per row, seed per cob, and grain yield per plant (Table 3 ) at genotypic level. Plant height showed significant positive correlation with cob length, cob breadth, $100 \mathrm{gm}$ seed weight at both the genotypic and phenotypic correlation coefficient (Table 3). Cob length showed significant positive correlation with cob breadth, $100 \mathrm{gm}$ seed weight, total seed weight at both the genotypic and phenotypic correlation coefficient (Table 3). Cob breadth showed significant positive correlation with the genotypic and phenotypic correlation coefficient (Table 3). Number of seed row per cob showed positive and significant correlation with days to female flowering, number of seed per row, seed per cob and 100-seed weight (Table 3). Number of seeds per row showed positive and significant correlation with days to days to maturity and cob length at genotypic level (Table 3). Number of seeds per cob showed positive and significant correlation with days to maturity, cob length, cob breadth, row per cob and seed per row (Table 3). 100-seed weight showed significant positive correlation with, plant height, cob length, number of seed per row and total yield per plant at both phenotypic and genotypic level of significance (Table 3).

\subsection{Path Analysis (Coefficient)}

The path coefficient analysis was first developed by [28] and demonstrated [29] in order to create the positioning of correlation coefficients into direct and indirect contribution of various characters of the yield. The correlation analysis indicates the association pattern of components traits with yield; representing 
overall influence of a particular trait on yield whereas path coefficient analysis provides cause and effect relationships of the component traits. Path coefficients are standardized versions of linear-regression coefficient analysis. It measures the direct influence of one variable upon other. It is a great deal for the breeders to know the cause-and-effect relations, direct and indirect relationships among the traits for further genetic improvement and research. The direct and indirect effects of path coefficient analysis are presented in Table 4.

\section{Conclusion}

The eleven component characters showed highly significant difference through analysis of variance. The maximum days to male flowering were estimated in genotype Cornell (68.0) and the minimum in genotype BHM-7 (61.0). The maximum day to female flowering was estimated in genotypeBHM-5 (66.67) and the minimum was in genotype Duranta (56.33). The maximum day to maturity was estimated in genotype Dekalb-30B07 (130.67); while the minimum in genotype Dekalb Super (127.00). Plant height ranged from the lowest 205.16 (BHM-6) to the highest 258.97 (PAC-399). The maximum cob length was estimated in genotype AS-999 $(18.87 \mathrm{~cm})$ and the minimum was in BHM-5 (14.90 $\mathrm{cm})$. The maximum cob breadth was estimated in genotype Dekalb-30B07 (17.30 $\mathrm{cm})$ and the minimum in genotype Shuvra $(12.5 \mathrm{~cm})$. The maximum number of seed row per cob was estimated in genotype Pacific $(22.38 \mathrm{~cm})$ and the minimum in genotype Misty $(12.57 \mathrm{~cm})$. The maximum number of seed row per cob was estimated in genotype PAC-559 (46.96) and the minimum in genotype BHM-14 (24.52). The maximum number of seed row per cob was estimated in genotype Pacific (798.95) and the minimum in genotype Dekalb Super (350.44). The maximum number of 100 -seed weight was estimated in genotype Duranta (39.67) and the minimum in genotype BHM-13 (27.33). The maximum grain yield was estimated in genotype Pacific-98 (117.51) and the minimum in genotype Dekalb Super (51.89).

Characters that are involved in this experiment such as days to male flowering, days to female flowering, days to maturity, plant height, cob length, cob breadth, number of rows per cob, number of grains per row, number of grains per cob, 100-seed weight and yield per plant showed higher heritability than genetic advance; at the same time phenotypic variability was also higher than genotypic variability. The maximum phenotypic variability was observed in number of grains per cob and the lowest in days to male flowering comparatively (Figure 1). The maximum heritability was observed in number of rows per cob 85.08 and the lowest in days to maturity 46.53 . High heritability accompanied with high to moderate GCV and genetic advance indicates most likely the heritability is due to additive gene effects. Among the eleven characters that were used in this investigation phenotypic coefficient of variation was comparatively higher than the genotypic coefficient of variation, whereas the highest phenotypic coefficient of variation was recorded in number of grains per cob (21.13) and the lowest in days to maturity (1.23). 
Here, the total yield showed positive and significant genotypic and phenotypic correlation coefficient with other concerning characters especially days to maturity, plant height, cob length, number of grains per cob and 100-seed weight. Days to male flowering, cob breadth, number of grains per cob and 100-seed weight revealed positive direct effects on yield per plant. On the other side days to female flowering, days to maturity, plant height, cob length, number of rows per cob and number of grains per row showed negative direct effects on yield per plant.

\section{Conflicts of Interest}

The authors declare no conflicts of interest regarding the publication of this paper.

\section{References}

[1] FAO (2016) World Agriculture: Towards 2015/2030 Summary Report. Rome.

[2] Tollenaar, M. and Dwyer, L.M. (1999) Physiology of Maize. In: Smith, D.L. and Hamel C., Eds., Crop Yield, Springer, Berlin, 169-204.

https://doi.org/10.1007/978-3-642-58554-8 5

[3] Khan, R. and Dubey, R.B. (2015) Combining Ability Analysis for Nutritional Quality and Yield in Maize (Zea mays L.). The Bioscan, 10, 785-788.

[4] BBS (2017) Statistical Yearbook of Bangladesh. Bangladesh Bureau of Statistics, Statistics Division, Ministry of Planning. Government of the People's Republic of Bangladesh, Dhaka, 9-190.

[5] BBS (2012) Statistical Yearbook of Bangladesh. Bangladesh Bureau of Statistics, Statistics Division, Ministry of Planning. Government of the People's Republic of Bangladesh, Dhaka.

[6] BBS, (2015) Statistical Yearbook of Bangladesh. Bangladesh Bureau of Statistics, Statistics Division, Ministry of Planning. Government of the People's Republic of Bangladesh, Dhaka.

[7] Naushad, A., Turi, S., Shah, S., Ali, S., Rahman, H., Ali, T. and Sajjad, M. (2007) Genetic Variability for Yield Parameters in Maize (Zea mays L.) Genotypes. Journal of Agricultural and Biological Science, 2, 1-3.

[8] Muhammad, B.A., Muhammad, R., Hussain, A., Tariq, M. and Sarwar, M. (2003) Character Association and Path Coefficient Analysis of Grain Yield Compoments Maize (Zea mays L.). Pakistan Journal of Biological Sciences, 6, 136-138. https://doi.org/10.3923/pjbs.2003.136.138

[9] OECD-FAO (2018) Agricultural Outlook 2018-2027.

[10] Abdurakhmonov, I. and Abdukarimov, A. (2008) Application of Association Mapping to Understanding the Genetic Diversity of Plant Germplasm Resources. International Journal of Plant Genomics, 4, 1-18. https://doi.org/10.1155/2008/574927

[11] Singh, P., Singh, P. and Mukul, K. (2013) Genetic Variability and Analysis of Yield Components in Linseed Germplasm. Annals of Agricultural Sciences, 16, 164-167.

[12] Sumanth, V., Suresh, B.G., Ram, B.J. and Srujana, G. (2017) Estimation of Genetic Variability, Heritability and Genetic Advance for Grain Yield Components in Rice (Oryza sativa L.). Journal of Pharmacognosy and Phytochemistry, 6, 1437-1439.

[13] Adhikari, B.N., Pokhrel, B.B. and Shrestha, J. (2018) Evaluation and Development 
of Fingermillet (Eleusine coracana L.) Genotypes for Cultivation in High Hills of Nepal. Farming \& Management, 3, 37-46. https://doi.org/10.31830/2456-8724.2018.0001.7

[14] Pal, S., Sharma, H.R., Rai, A.K. and Bhardwaj, R.K. (2016) Genetic Variability, Heritability and Genetic Gain for Yield and Quality Traits in Cucumber (Cucumis sativus L.) Genotypes. The Bioscan, 11, 1985-1990.

[15] Girma, B.T., Kitil, M.A., Banje, D.G., Biru, H.M. and Serbessa, T.B. (2018) Genetic Variability Study of Yield and Yield Related Traits in Rice (Oryza sativa L.) Genotypes. Advances in Crop Science and Technology, 6, 381.

[16] Shukla, S., Bhargava, A., Chatterjee, A., Srivastava, A. and Singh, S.P. (2006) Genotypic Variability in Vegetable Amaranth (Amaranthus tricolor L.) for Foliage and Its Contributing Traits over Successive Cuttings and Years. Euphytica, 151, 103-110. https://doi.org/10.1007/s10681-006-9134-3

[17] Aditya, J.P. and Bhartiya, A. (2013) Genetic Variability, Correlation and Path Analysis for Quantitative Characters in Rainfed Upland Rice of Uttarakhand Hills. Journal of Rice Research, 6, 24-34.

[18] FAO-UNDP (1988) Land Resources Appraisal of Bangladesh for Agricultural Development. Report 2. Agroecological Regions of Bangladesh. FAO, Rome, 570.

[19] Rahman, M.M. and Alam, M. (2010) Disappearing Forest Tree Species Diversity in Tropical Moist Deciduous Forest and Its Implications: A Case Study in the Madhupur Tract of Central Bangladesh. Journal of Forest Science, 26, 161-170.

[20] SRDI (2001) Land and Soil Resources Utilization Guide (In Bengali) Upazila Nirdeshica Series-Madhupur Upazila. Soil Resources Development Institute, Dhaka.

[21] Gomez, K.A. and Gomez, A.A. (1984) Statistical Procedure for Agricultural Research. 2nd Edition, Willey, Hoboken, 28-192.

[22] Jason, A.P., Maria C.R., Michael, A., Sherry, A. and Edward, S.B. (2014) The Genetic Architecture of Maize Height. Genetics, 196, 1337-1356. https://doi.org/10.1534/genetics.113.159152

[23] Anshuman, V., Dixit, N.N., Sharma, D. and Marker, S. (2013) Studies of Heritability and Genetic Advance Estimates in Maize Genotypes. Bioscience Discovery, 4, 165-168.

[24] Juliet, S.H., Geetha, K. and Ibrahim, S.M. (2013) Evaluation of Genetic Diversity, Variability, Character Association and Path Analysis in Diverse Inbreds of Maize (Zea mays L.). Electronic Journal of Plant Breeding, 4, 1067-1072.

[25] Rafiq, M., Amer, H. and Muhammad, A. (2010) Studies on Heritability, Correlation and Path Analysis in Maize (Zea mays L.). Journal of Agricultural Research, 48, 177-190.

[26] Rajesh, S., Kumar, S., Narsimha, R.V. and Sankar, A.S. (2013) Studies on Genetic Variability, Heritability and Genetic Advance Estimates in Newly Developed Maize Genotypes (Zea mays L.). International Journal of Applied Biology and Pharmaceutical Technology, 4, 242-245.

[27] Debnath, S.C. (1987) Genetic Variability in Maize (Zea mays L.). Bangladesh Journal of Agriculture, 12, 217-222.

[28] Wright, S. (1921) Correlation and Causation. Journal of Agricultural Research, 20, 557-585.

[29] Dewey, D.R. and Lu, K.H. (1959) A Correlation and Path Coefficient Analysis of Components of Creast Wheat Grass Seed Production. Agronomy Journal, 57, 342-346. 